\title{
Exposure to moderately elevated temperatures changes food preferences in the tropical marine herbivore Haliotis squamata
}

\author{
Veronika Mitterwallner ${ }^{1,4} \cdot$ An Nisa Nurul Suci ${ }^{2} \cdot$ Neviaty Zamani $^{2} \cdot$ Mark Lenz $^{3}$
}

Received: 5 October 2020 / Accepted: 9 June 2021 / Published online: 19 June 2021

(c) The Author(s) 2021

\begin{abstract}
Ocean warming is affecting marine ectothermic herbivores as well as the macroalgal species they consume and this has the potential to alter their trophic interaction. However, it is currently still unknown how these two important components of benthic food webs will react to a warming environment. Consumption rates of grazers change with increasing temperatures, but it is unclear whether this is also true for feeding preferences. In this study, multiple-choice feeding assays with the tropical abalone Haliotis squamata from Western Indonesia were conducted in August 2018. After brief acclimation of either the grazer or the macroalgae to moderately elevated water temperatures (maximum $2{ }^{\circ} \mathrm{C}$ above the long-term average) in the laboratory, three species of living macroalgae were simultaneously offered to the abalone in feeding assays. Consumption rates of $H$. squamata were lower under elevated water temperatures, while its feeding preference switched: At $27{ }^{\circ} \mathrm{C}$ $\left(2{ }^{\circ} \mathrm{C}\right.$ below long-term average), abalone preferred non-acclimated Gracilaria salicornia, but switched to non-acclimated Amphiroa spp. at $31^{\circ} \mathrm{C}$. Interestingly, no such switch in preference occurred when the macroalgae, but not the grazers were acclimated. This indicates that the grazer will presumably be the driver of this potential change in interactions between $H$. squamata and its macroalgal food. Ocean warming may result in changes in the structure of benthic communities, mediated by changes in the feeding behaviour of herbivorous invertebrates.
\end{abstract}

\section{Introduction}

Climate change is affecting marine ecosystems worldwide. In the last 50 years, an increase in the temperature of the upper ocean of $0.11^{\circ} \mathrm{C}$ was documented and sea surface temperature is predicted to rise further (IPCC Working

Responsible Editor: J. Grassle.

Reviewers: C. Mundy and anundisclosed expert.

Veronika Mitterwallner

veronika.mitterwallner@uni-bayreuth.de

1 Department of Animal Ecology I, University Bayreuth, Universitätsstr. 30, 95440 Bayreuth, Germany

2 Department of Marine Science and Technology, Faculty of Fisheries and Marine Sciences, IPB University, Jl. Agatis No.1, Bogor 16680, West Java, Indonesia

3 Department of Marine Ecology, GEOMAR Helmholtz Centre for Ocean Research Kiel, Düsternbrooker Weg 20, 24105 Kiel, Germany

4 Department of Sport Ecology, Institute of Sport Science, University Bayreuth, Universitätsstr. 30, 95440 Bayreuth, Germany
Group 1 2013b). In their 5th report, the IPCC working group 1 predicted an increase of $1-3{ }^{\circ} \mathrm{C}$ by the end of this century, depending on the emission scenario considered, with the strongest warming in ocean surface waters in subtropical and tropical regions (IPCC Working Group 1 2013a).

Water temperature is one of the most important abiotic factors influencing the performance of marine ectothermic organisms, as their metabolic rates are a function of the prevailing ambient temperature (Somero 2002). This has consequences for their distribution and abundances, which in turn control the structure and functioning of entire ecosystems. Since the capacity to adapt to temperature fluctuations varies among marine ectotherms, species possess thermal niches that differ in size, specific optima and upper limits (Somero and Hochachka 1971; Pörtner 2010; Schulte et al. 2011; Vasseur et al. 2014). Following the concept of oxygen- and capacity-limited thermal tolerance put forward by Pörtner (2010), the aerobic scope at the lower and upper limit of a thermal niche is limited by insufficient oxygen supply. In tropical ectotherms, the upper limit of the thermal tolerance range tends to be close to the maximum temperature of their habitat and these systems exhibit very little annual variation in temperature. Adaptations to extreme fluctuations are thus 
not required in these organisms (Pörtner and Knust 2007). For that reason, tropical ectotherms have a low acclimation ability and tolerance of elevated water temperatures. Thus, they are considered highly sensitive to future ocean warming (Nguyen et al. 2011).

Elevated temperatures increase metabolic rates in ectotherms (Clarke and Fraser 2004) and, as a consequence, the animals commonly cover enhanced energy demands by increasing their food intakes (Hill and Magnuson 1990). This behaviour has, at least theoretically, the potential to intensify the interaction between herbivores and macroalgae (O'Connor et al. 2009). However, rising temperatures do not only affect grazers but also their food organisms. Several studies showed that elevated temperatures impair inducible defences and lead to the softening and the loss of tissue in kelp (Weinberger et al. 2011; Andersen et al. 2013; Rothäusler et al. 2017). Furthermore, the nutritional value of macroalgae, which is determined by their protein and lipid contents, decreases under elevated temperatures (Schram et al. 2017). Alterations in the nutritional value and in the effectiveness of anti-herbivore defences can, in turn, alter the palatability of the affected macroalgae for consumers (Poore et al. 2013). It is therefore plausible that the coincidence of elevated metabolic rates in a herbivore and a reduction in the defence capacity of its macroalgal prey will enhance consumption by the grazer. This has already been demonstrated by Alcantara and Noro (2005), who observed that the consumption rates of the abalone Haliotis diversicolor increased with increasing water temperature.

However, not only herbivore consumption rates, but also their feeding preferences are relevant for the dynamics in algal communities (Lubchenco and Gaines 1981). Changes in the food preference of herbivores have the potential to modify algal-grazer interactions and this may alter the structure of benthic ecosystems that are stabilised by this key interaction, such as kelp forests and coral reefs (Leibold et al. 1997; Hughes et al. 2003). However, so far little is known about temperature-induced changes in grazing regimes in coral reefs (Johnson and Carpenter 2012), since few studies have addressed the performance and food choices of tropical benthic herbivores under elevated water temperatures. Sea surface temperatures in the Indian Ocean are predicted to rise by $1-4{ }^{\circ} \mathrm{C}$ by the end of the century (Hoegh-Guldberg et al. 2014). Hence, to assess the implications of such a rise for the structure and functioning of shallow-water benthic ecosystems, it is vital to learn more about the influence of ocean warming on tropical algal-grazer interactions.

We tested whether the feeding behaviour (i.e. feeding rates and feeding preference) of the abalone Haliotis squamata changes under elevated water temperatures. Abalone are common on tropical coral reefs, where they actively graze on several species of micro- and macroalgae or trap drifting algal fragments (Tutschulte and Connell 1988;
Geiger 2000; Zeeman et al. 2012, 2014). Haliotis squamata is a relatively small species ( $\sim 50 \mathrm{~mm}$ shell length) and is known to graze on several macroalgal species that are common on Indonesian coral reefs (Susanto et al. 2010; Bachry et al. 2019). We used feeding assays either with acclimated abalone (fed with non-acclimated macroalgae) or with acclimated macroalgae (Sargassum spp., Gracilaria salicornia. and Amphiroa spp.), which were offered to nonacclimated abalone to answer two questions. (1) Do feeding rates in $H$. squamata follow a unimodal performance curve across the temperature range we applied? (2) Does the herbivore change its dietary composition when water temperatures rise? Furthermore, our approach allowed us to identify which of the two system components, i.e. the herbivore or the macroalgae, is responsible for a change in feeding preference.

\section{Materials and methods}

\section{Herbivores and macroalgal food}

Juvenile Haliotis squamata are the herbivores used in this study. Marine gastropods in the family of the Haliotidae are distributed worldwide, but are most diverse in the IndoMalayan area (Geiger 2000). Haliotis squamata occurs along the coasts of western and north-western Australia as well as in the Indonesian archipelago (Geiger 2000). The species forages either by inactively catching drift algae or by actively grazing on benthic macroalgae at night (Shepherd 1973; Tutschulte and Connell 1988). There is evidence that H. squamata prefers to feed on red algae (Yusup et al. 2020) and Tahil and Juinio-Menez (1999) and Angell et al. (2012) also found a clear preference for red macroalgae in Haliotis asinina, another Indo-Malayan species.

All individuals used in this study hatched (multiple broods from F0 H. squamata) at Balai Besar Riset Budidaya Laut dan Penyuluhan Perikanan in Bandjargondol on the island of Bali (Indonesia) ( $8^{\circ} 09^{\prime} 21.45^{\prime}$ 'S; 114 ${ }^{\circ} 42^{\prime} 51.39^{\prime}$ 'E) and were transported to Bogor by airplane and road within $5 \mathrm{~h}$. During this time, the abalone were kept dry, in air-filled plastic bags in cooled Styrofoam boxes. All experiments took place in the Marine Habitat Laboratory of IPB University in Bogor, Java, Indonesia. The use of $H$. squamata hatchlings in this study had the advantage that all individuals had similar shell lengths (22-25 mm).

Two different types of food, i.e. food pellets and fragments of living algae, were used for the feeding assays. To test whether food consumption is a function of temperature (Experiment 1), we produced agar-pellets containing Ulva lactuca powder (Xi'an XiaoCao Botanical Development Co., Ltd, China). Ulva lactuca is commonly used as food for abalone in hatcheries and is known to be consumed by $H$. 
squamata (Giri et al. 2016; Heru Prihadi et al. 2018; Yusup et al. 2020). For the pellets, we mixed $7.2 \mathrm{~g}$ of agar powder with $100 \mathrm{~mL}$ of distilled water and boiled the mixture for $5 \mathrm{~s}$ in a microwave ( 800 watts). Then, $20 \mathrm{~g}$ of algal powder, which we previously mixed with $80 \mathrm{~mL}$ of distilled water, were added to the warm agar. The resulting homogenous mass was poured into silicone forms $(1 \times 0.5 \times 1 \mathrm{~cm})$ to form uniform food pellets. Pellets were fed to the abalone immediately after they had cooled to room temperature.

For the assays, in which we tested whether the diet composition of $H$. squamata changes with temperature (Experiment 2), fragments of living macroalgae from the Bay of Tidung Island, Thousand Islands, Indonesia, were used. We collected specimens of the red macroalga Gracilaria salicornia and algae belonging to several species of Amphiroa (Rhodophyta) and Sargassum (Phaeophyceae), respectively, on 22 July 2018 (Supplement Table S1). Macroalgae were carefully detached from the substratum and placed in plastic bags filled with seawater $\left(20^{\circ} \mathrm{C}\right)$ for transport to the Marine Habitat Laboratory in Bogor. There, they were transferred to large aquaria $(105 \mathrm{~L}$ and $210 \mathrm{~L}$ ) containing seawater from a recirculating water system $(1000 \mathrm{~L})$ with a gravel filter. The water in the aquaria was aerated and was moved by submersible pumps. Light was supplied by LED aquarium lamps and once a week fertiliser (Flora Green, Fish-All) was added. All macroalgae that we collected for the experiments occur in high abundances on the coral reefs that are the natural habitat of H. squamata in Western Indonesia. In accordance with this, the abalone fed readily on each of the algal taxa when we offered them separately (Mitterwallner, pers. obs.). To avoid any bias, which could relate to the food that the abalone received in the hatchery, we offered them a mixed diet consisting of equal amounts of thallus tips from all three macroalgae every second day.

\section{Experiment 1: influence of temperature on food consumption rate}

In Experiment 1, food consumption rates of Haliotis squamata were measured after the abalone had been acclimated to five temperature levels, ranging $27-33{ }^{\circ} \mathrm{C}$ at $1.5^{\circ} \mathrm{C}$ intervals to identify the appropriate temperature range for Experiment 2. The lowest temperature, $27^{\circ} \mathrm{C}$, was $2{ }^{\circ} \mathrm{C}<$ ambient sea surface temperature (SST) in the Bali Strait averaged over the last 5 years (NOAA data processed with SeaDAS 7.5), while the highest temperature, $33^{\circ} \mathrm{C}$, reflects the $4{ }^{\circ} \mathrm{C}$ increase in SST predicted for the Indian Ocean by the end of this century (Hoegh-Guldberg et al. 2014). After a laboratory acclimation period of $7 \mathrm{~d}$, during which the $H$. squamata were kept at $27^{\circ} \mathrm{C}$, they were transferred individually to plastic containers $(1.5 \mathrm{~L})$ to allow acclimation to the target temperatures. Each plastic container served as an experimental unit and was placed in one of five water baths $(2 \times 400 \mathrm{~L}, 2 \times 495 \mathrm{~L}, 1 \times 800$ L: 20 experimental units per water bath). The water bodies inside the single experimental units and in the water baths were strictly separated and no exchange between them occurred during the experiment. Water baths were equipped with electric aquarium heaters that were regulated by temperature control units (HOBBY Biotherm Pro) and each water bath had a logger (HoBo onset logger) to monitor the realised water temperature throughout the experiment. Additional temperature measurements were taken from the experimental units twice a day to check for any temperature gradients inside the water baths (Supplement Table S2). Each experimental unit was aerated individually to ensure a sufficient oxygen supply and we exchanged $50 \%$ of the water manually every day to avoid the accumulation of toxic metabolites. After all abalone had spent 3 days at $27^{\circ} \mathrm{C}$, we started to increase the water temperature by $1{ }^{\circ} \mathrm{C}$ per day $\left(0.5{ }^{\circ} \mathrm{C}\right.$ in the morning and $0.5^{\circ} \mathrm{C}$ in the evening). To ensure that all target temperatures were reached on the same day, temperature increases in the different water baths were initiated successively. Hence, acclimation to the highest target temperature was started first. After all targeted temperatures were reached, we kept the abalone at these temperatures for another 3 days and then conducted the feeding assays, which lasted for $24 \mathrm{~h}$. The assays started on 25 June 2018 and were done within the experimental units to avoid potential stress associated with transferring the abalone to other containers. During the assays, each individual abalone (i.e. each replicate) was offered a pre-weighed Ulva lactuca pellet. It was removed from the experimental unit immediately after the assay and was weighed to identify the amount of pellet material consumed by $H$. squamata. The same procedure was done with an equal number $(n=20)$ of extra pellets per temperature level, which were kept under the same conditions, while no grazer was there to feed on them. Weighing the extra pellets before and after the feeding assays allowed us to assess the autogenic change in the food pellets that may have occurred, e.g. due to soaking in water. Feeding rates were calculated with the following formula:

$$
\begin{aligned}
& \text { Feedingrate }=\frac{\frac{\text { pelletDW }_{\text {initial }} * \text { autochangeDW }_{\text {initial }}}{\text { autochangeDW }_{\text {final }}}-\text { pelletDW }_{\text {final }}}{\text { grazerDW }_{\text {time }}} \\
& =\frac{[g]}{[g] *[d]}=g g^{-1} d^{-1}
\end{aligned}
$$

Mortality among abalone during temperature acclimation led to an unbalanced design in the feeding assays. There were 18-20 individuals per temperature level, except for the highest temperature at which $85 \%$ of the individuals died during acclimation, leaving only three replicates for 
statistical analysis. Abalone mortality rates during the experiments reported in here were published by Suci et al. (2019).

\section{Experiment 2: influence of temperature on diet composition}

In Experiment 2, we investigated the feeding preferences of Haliotis squamata under the different target temperatures. Unlike Experiment 1, where food pellets were used, we offered living algae belonging to three taxa (Gracilaria salicornia, Amphiroa spp. and Sargassum spp.). Thallus fragments from the three different algae were offered simultaneously. Furthermore, we ran the feeding assays with acclimated herbivores $(\mathrm{AH})$ and non-acclimated algae (NA) as well as with non-acclimated herbivores $(\mathrm{NH})$ and acclimated algae (AA). As in Experiment $1, H$. squamata individuals were acclimated individually in plastic containers within different water baths, whereas macroalgae were kept together in larger aquaria $(105 \mathrm{~L}$ and $201 \mathrm{~L})$. The water temperatures inside the aquaria were adjusted with aquarium heaters controlled by regulator units (Supplement Table S3). The concept of Experiment 2 was in large parts identical with Experiment 1, but acclimation at the target temperatures in Experiment 2 lasted for $10 \mathrm{~d}$, giving more time for the macroalgae to adapt. Moreover, we only used three temperature levels, i.e. $27^{\circ} \mathrm{C}, 29^{\circ} \mathrm{C}$ and $31^{\circ} \mathrm{C}$. The $33^{\circ} \mathrm{C}$ level was omitted, because of the high abalone mortality at this temperature (Suci et al. 2019). Hence, Experiment 2 consisted of five experimental groups. In the first, neither the herbivore nor the algae were acclimated to elevated temperatures, but were kept at $27^{\circ} \mathrm{C}$. The two experimental scenarios (i.e. $\mathrm{AH}+\mathrm{NA}$ and $\mathrm{NH}+\mathrm{AA}$ ) were both realised at two temperature levels and these combinations of experimental scenario and temperature constituted the four remaining experimental groups (Fig. 1).

The feeding assays again lasted for $24 \mathrm{~h}$ and were conducted on 9 August 2018. We provided thallus tips to herbivores, which were similar to each other with regard to their surface area. This was done to ensure that the different algal species were offered to the grazers in comparable amounts. In addition, any autogenic change, e.g. due to growth or tissue loss, in the algal pieces during the feeding assays was assessed in extra experimental units $(n=9$ for $\mathrm{H}$ and $\mathrm{A}$ at $27{ }^{\circ} \mathrm{C}, n=9$ for $\mathrm{AH}+\mathrm{NA}$ at $29^{\circ} \mathrm{C}, n=9$ for $\mathrm{AH}+\mathrm{NA}$ at $31{ }^{\circ} \mathrm{C}, n=9$ for $\mathrm{NH}+\mathrm{AA}$ at $29^{\circ} \mathrm{C}$ and $n=1$ (Amphiroa spp.), 2 (Sargassum spp.), 9 (G. salicornia) for NH+ AA at $31{ }^{\circ} \mathrm{C}$ ) that did not contain herbivores. For the assays, the algal pieces were placed in a triangle around each abalone. They were all at the same distance, i.e. twice the abalone's SL from each other and from the herbivore. Feeding rates were calculated following the same formula as in Experiment 1 . To remove adherent water prior to weighing, all algal pieces were blotted with a microfibre tissue.
Fig. 1 Experiment 2 consisted of five experimental groups: No acclimation at $27^{\circ} \mathrm{C}$, and acclimation of either herbivores $(\mathrm{AH}+\mathrm{NA})$ or algae $(\mathrm{NH}+\mathrm{AA})$ to two elevated temperatures $\left(29^{\circ} \mathrm{C}\right.$ and $\left.31^{\circ} \mathrm{C}\right)$. Replication was 9 in each group. $\mathrm{T}=$ temperature. Colour coding indicates which component of the trophic system was acclimated

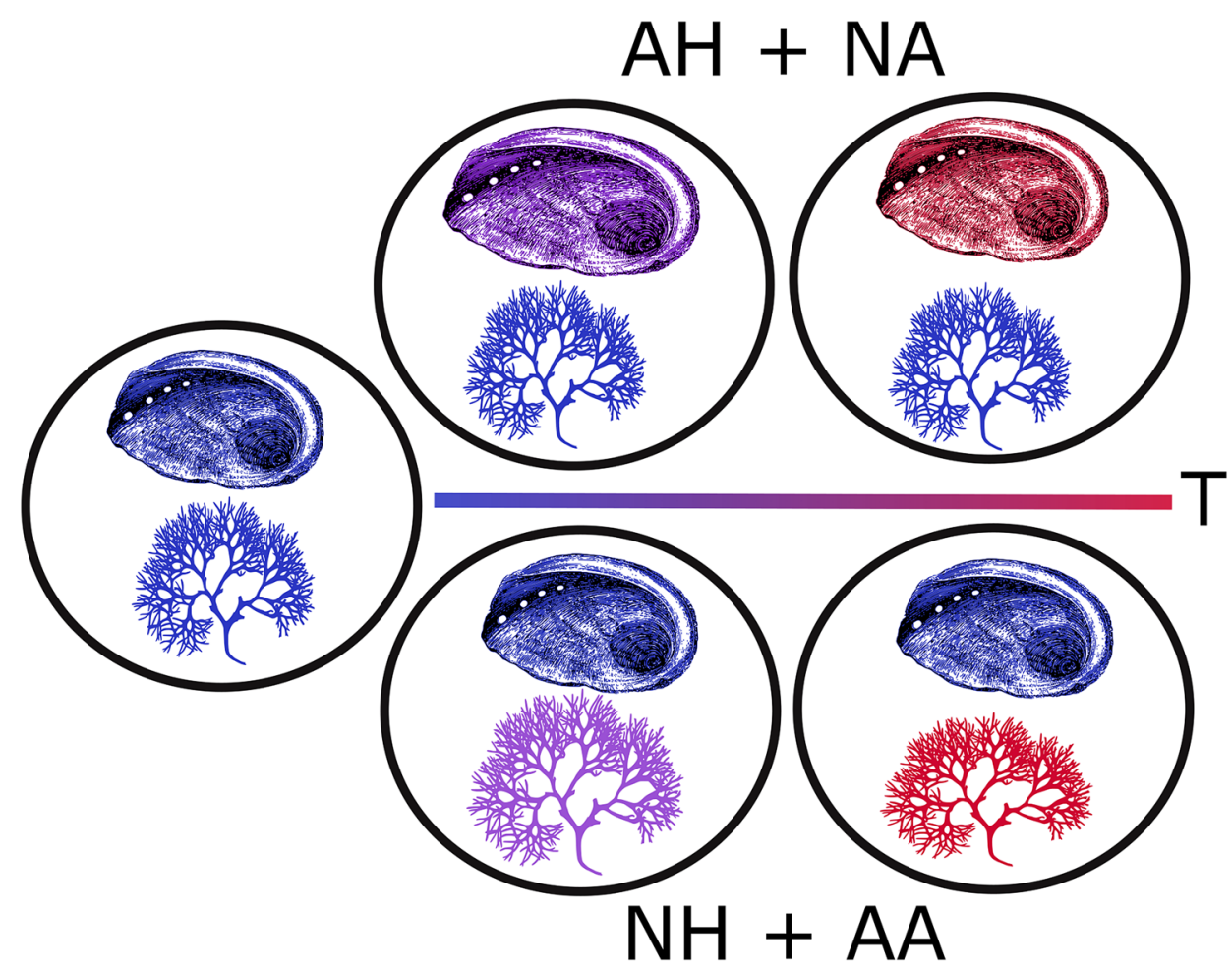




\section{Statistical analyses}

In Experiment 1, the design was unbalanced because mortality among the abalone differed between the target temperatures. The number of replicates per group ranged from 20 individuals $\left(31.5^{\circ} \mathrm{C}\right)$, over $19\left(27^{\circ} \mathrm{C}\right)$ and $18\left(28.5^{\circ} \mathrm{C}\right.$ and $\left.30{ }^{\circ} \mathrm{C}\right)$ to three $\left(33^{\circ} \mathrm{C}\right)$. In Experiment 2, in both experimental scenarios (i.e. $\mathrm{AH}+\mathrm{NA}$ and $\mathrm{NH}+\mathrm{AA}$ ), we had nine replicates for each of the three target temperatures. This resulted in 5 treatment combinations (Fig. 1) with 45 individuals in total. A few abalone did not feed within the 24-h feeding assays and were excluded from the analysis.

To assess the effect of temperature on the performance of Haliotis squamata, we analysed the feeding rates as a function of temperature (five levels: $27^{\circ} \mathrm{C}, 28.5^{\circ} \mathrm{C}, 30^{\circ} \mathrm{C}$, $31.5^{\circ} \mathrm{C}, 33{ }^{\circ} \mathrm{C}$ ) using a simple regression based on a quadratic function (2nd degree polynomial). This was done to test our hypothesis about a unimodal relationship between temperature and abalone performance. Such a relationship, if present, would indicate that we actually covered the temperature at which food consumption in H. squamata peaks. For the regression, temperature was treated as a continuous independent variable and homogeneity of variances was confirmed by plotting the residuals against the fitted values. Furthermore, the residuals were tested for normality with histograms.

In Experiment 2, the influence of temperature on feeding rates was analysed using Analysis of Variance (ANOVA) after log-transforming the data. Again, we confirmed homogeneity of variances by plotting the residuals against the fitted values and tested for normality by inspecting histograms of the residuals.

To test for differences in the diet composition of $H$. squamata, which may have resulted from a temperature-induced change in its feeding preference, Permutational Analysis of Variance (PERMANOVA) was used. For this, we used a two-factorial design with temperature and the experimental scenario (i.e. $\mathrm{AH}+\mathrm{NA}, \mathrm{NH}+\mathrm{AA}$ ) as fixed factors and the amounts of the different macroalgae consumed by the abalone in the feeding assays as the response variables. PERMANOVA was calculated using the Bray-Curtis dissimilarities and consumption rates were not transformed prior to calculation. For all analysis, the statistical software R 3.4.4. and the package 'vegan'(Oksanen et al. 2019) was used.

\section{Results}

\section{Experiment 1: influence of temperature on feeding rates}

Feeding rates in Haliotis squamata were, with a median of $1.5 \mathrm{~g} \mathrm{~g}^{-1} \mathrm{~d}^{-1}$, highest at the two lowest temperatures $\left(27^{\circ} \mathrm{C}\right.$ and $28.5{ }^{\circ} \mathrm{C}$ ), but decreased significantly with increasing temperature (polynomial regression: $\mathrm{F}(1,76)=5.84$; $\left.\mathrm{r}^{2}=0.059 ; \mathrm{P}=0.018\right)$. At the highest water temperature $\left(33^{\circ} \mathrm{C}\right)$, the surviving individuals almost stopped feeding (Fig. 2).
Fig. 2 Consumption of food pellets by Haliotis squamata after individuals were acclimated to different temperatures. $27^{\circ} \mathrm{C}: n=19 ; 28.5^{\circ} \mathrm{C}: n=18$; $30{ }^{\circ} \mathrm{C}: n=18 ; 31.5^{\circ} \mathrm{C}: n=20$; $33^{\circ} \mathrm{C}: n=3$

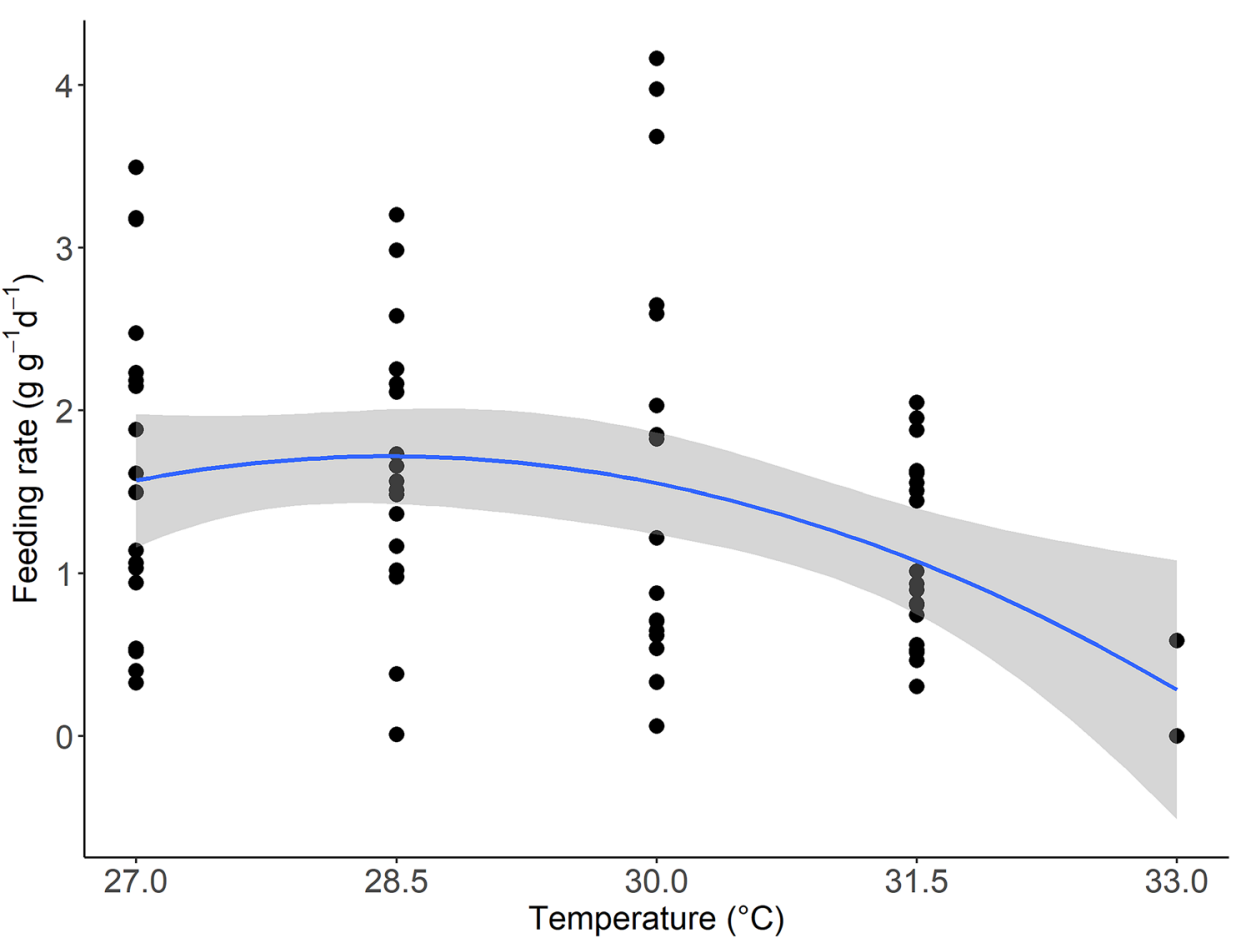




\section{Experiment 2: influence of temperature on diet composition}

Similar to Experiment 1, the feeding rates of Haliotis squamata in Experiment 2, which were summed across all algal fragments offered in one assay, declined with increasing temperature. In abalone acclimated to $27{ }^{\circ} \mathrm{C}$ the consumption of living algal material was $0.75 \mathrm{~g} \mathrm{~g}^{-1} \mathrm{~d}^{-1}$ higher than in conspecifics acclimated to $31{ }^{\circ} \mathrm{C}$ and the picture was similar when algal fragments were acclimated (Fig. 3). These effects were not statistically significant.

When the abalone were acclimated to elevated temperatures (i.e. scenario AH+NA), the diet composition of $H$. squamata changed, because its feeding preference shifted towards Amphiroa spp. When exposed to $27{ }^{\circ} \mathrm{C}, \mathrm{H}$. squamata clearly preferred Gracilaria salicornia $\left(1.1 \mathrm{~g} \mathrm{~g}^{-1} \mathrm{~d}^{-1}\right)$ over Amphiroa spp. $\left(0.1 \mathrm{~g} \mathrm{~g}^{-1} \mathrm{~d}^{-1}\right)$ and Sargassum spp. $\left(0 \mathrm{~g} \mathrm{~g}^{-1} \mathrm{~d}^{-1}\right)$. However, this preference changed with increasing temperature as feeding on G. salicornia declined from $>1 \mathrm{~g} \mathrm{~g}^{-1} \mathrm{~d}^{-1}$ at $27{ }^{\circ} \mathrm{C}$ to almost $0 \mathrm{~g} \mathrm{~g}^{-1} \mathrm{~d}^{-1}$ at the highest temperature $\left(33^{\circ} \mathrm{C}\right)$ (Fig. 4). At $29^{\circ} \mathrm{C}$, the herbivores consumed similar amounts of G. salicornia and Amphiroa spp. $\left(\sim 0.3 \mathrm{~g} \mathrm{~g}^{-1} \mathrm{~d}^{-1}\right)$, while the consumption of Amphiroa spp. increased from $0.1 \mathrm{~g} \mathrm{~g}^{-1} \mathrm{~d}^{-1}$ at $27{ }^{\circ} \mathrm{C}$ to $0.5 \mathrm{~g} \mathrm{~g}^{-1} \mathrm{~d}^{-1}$ at $31{ }^{\circ} \mathrm{C}$. At none of the experimental temperatures were Sargassum spp. the preferred macroalgae, and none of it was consumed (Fig. 4). The effect of temperature and experimental scenario on diet composition was significant (Table 1).

A different picture emerged when the macroalgae instead of the herbivores were acclimated to increased temperatures prior to the feeding assays (i.e. scenario $\mathrm{NH}+\mathrm{AA})$. No change in the dietary preferences of $H$. squamata was detected, G. salicornia remained the preferred food regardless of the temperature to which the algae were previously acclimated (Fig. 4). However, $H$. squamata showed an even more pronounced preference for G. salicornia, with a mean feeding rate $>1.0 \mathrm{~g} \mathrm{~g}^{-1} \mathrm{~d}^{-1}$, when the macroalga was kept at the lowest temperature $\left(27^{\circ} \mathrm{C}\right)$ prior to the feeding assays. The amounts of Amphiroa spp. that were consumed were highest when the alga was acclimated to $29^{\circ} \mathrm{C}$, while consumption of Amphiroa spp. was almost zero when the alga was acclimated to $27^{\circ} \mathrm{C}$ or to $33^{\circ} \mathrm{C}$ (Fig. 4). Again, in this scenario (NH + AA) H. squamata did not feed on Sargassum spp., regardless of the temperature to which the macroalgae were acclimated (Fig. 4). Therefore, dietary preferences

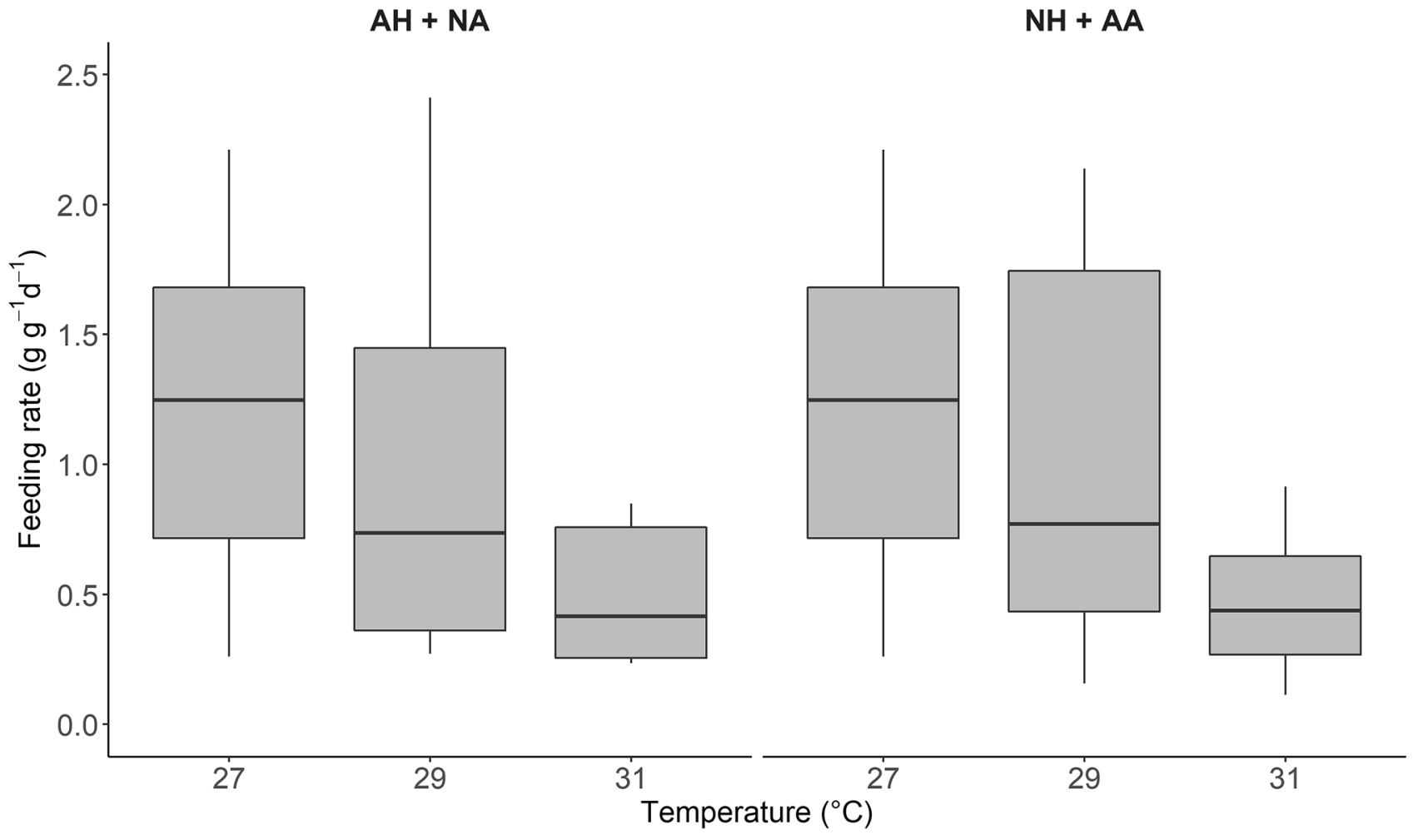

Fig. 3 Consumption of living macroalgae (three species pooled) by Haliotis squamata, after only herbivores had been acclimated to difhad been acclimated to different temperatures (scenario $\mathrm{NH}+\mathrm{AA}$ ). ferent temperatures (scenario $\mathrm{AH}+\mathrm{NA}$ ) and after only macroalgae 
Fig. 4 Consumption of living macroalgae by Haliotis squamata after only the herbivore had been acclimated to different temperatures (scenario $\mathrm{AH}+\mathrm{NA}$ ) and after only the macroalgae had been acclimated to different temperatures (scenario $\mathrm{NH}+\mathrm{AA}$ ). Boxplots show interquartile range, median and non-outlier range

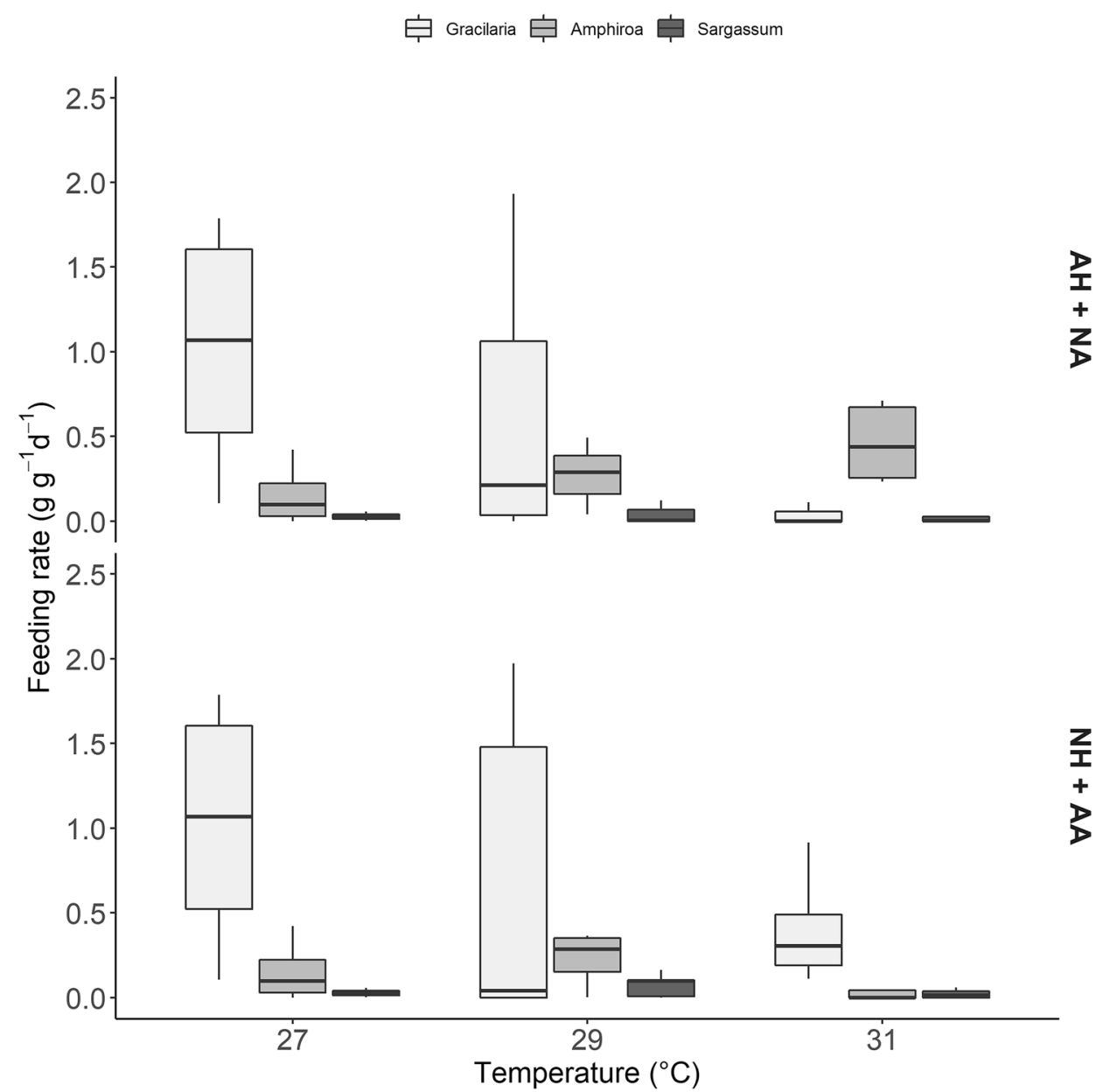

Table 1 Influence of temperature and of the experimental scenario on the diet composition of Haliotis squamata. Results from Permutational Analysis of Variance (PERMANOVA)

\begin{tabular}{llllllr}
\hline & df & Sums of squares & Mean squares & $F$ & $R^{2}$ & 0.015 \\
Temperature & 2 & 0.6191 & 0.30956 & 3.756 & 0.09688 \\
Experimental scenario & 1 & 0.9961 & 0.99607 & 10.8618 & 0.15586 & 0.001 \\
$\begin{array}{l}\text { Temperature: experimental } \\
\text { scenario }\end{array}$ & 1 & 1.2908 & 1.29082 & 14.0760 & 0.20198 & 0.002 \\
\hline
\end{tabular}

of the abalone did not change when the macroalgae instead of the herbivores were acclimated to different temperatures. The diet composition of the abalone was significantly influenced by the experimental scenario $(\mathrm{AH}+\mathrm{NA}$ vs. $\mathrm{NH}+\mathrm{AA}$ ) as well as by water temperature. The fact that diet composition changed with increasing water temperature when the herbivores but not the macroalgae were acclimated $(\mathrm{AH}+\mathrm{NA})$, while no such effect emerged when the macroalgae were acclimated $(\mathrm{NH}+\mathrm{AA})$ led to a significant interaction between the experimental scenario and temperature (Table 1).

\section{Discussion}

In the first experiment of this study, which investigated the relationship between water temperature and food consumption in Haliotis squamata, exposure to elevated temperatures decreased survival in the tropical gastropod. This was most pronounced at the highest temperature $\left(33^{\circ} \mathrm{C}\right)$. Furthermore, food consumption in $H$. squamata was lower at all water temperatures $>3{ }^{\circ} \mathrm{C}$ above the ambient temperature of $27{ }^{\circ} \mathrm{C}$. An increase in the water temperature by $4.5^{\circ} \mathrm{C}$ resulted in a decrease in food consumption by $32 \%$, while the latter was lowered by $88 \%$ when temperature 
was increased by $6{ }^{\circ} \mathrm{C}$. In the second experiment, which additionally addressed the influence of temperature on diet composition in $H$. squamata, an increase in water temperature by $2{ }^{\circ} \mathrm{C}$ lowered feeding by $19 \%$, while an increase of $4{ }^{\circ} \mathrm{C}$ reduced it by $31 \%$.

Depending on the thermal tolerance of the test organisms and the applied temperature range, previous studies on invertebrate food consumption revealed either an increase or a decrease in feeding rates with increasing temperatures. The first is commonly observed when the chosen temperatures are lower than the species-specific temperature of optimal performance (Cruz-Rivera and Hay 2000; Alcantara and Noro 2005; O'Connor et al. 2009; Zhang et al. 2016), while the second is encountered when temperatures are higher than the temperature of optimal performance (Poore et al. 2013; Pagès et al. 2017). Our observation that feeding rates in $H$. squamata declined even if the water temperature was only slightly elevated could indicate that in the coastal waters of Western Indonesia, where this herbivore lives, H. squamata is already at or even beyond the temperature at which it performs best. However, there is evidence that populations of other species of Haliotis can adapt to ocean warming through the selection of heat stress-tolerant genotypes (Miller et al. 2019; Shiel et al. 2020). The Indonesian populations of $H$. squamata presumably also have a genetic diversity that would allow for an increase in frequency of stresstolerant genotypes during the course of ocean warming. This process could stabilise abalone populations in the future.

In the face of heat stress, processes such as growth, reproduction and food consumption may be suppressed to save energy and the affected organism usually goes into a metabolic depression (Pörtner and Knust 2007). This extends the time span for which ectothermic organisms can tolerate heat stress conditions (Pörtner and Knust 2007). Metabolic depression as the consequence of acute or chronic exposure to elevated temperatures has experimentally been shown for several marine invertebrate species such as the sea urchins Heliocidaris erythrogramma (Harianto et al. 2018) and Evechinus chloroticus (Christensen et al. 2011; Delorme and Sewell 2016) as well as for the brittle star Ophionereis schayeri and the intertidal gastropod Littorina saxatilis (Sokolova and Pörtner 2001).

To avoid negative consequences of heat stress, many marine invertebrates have the capacity to modify their thermal window by acclimation or adaptation (Pörtner et al. 2009; Schulte et al. 2011). In our study, we therefore allowed acclimation by increasing the water temperature by only $1{ }^{\circ} \mathrm{C} \mathrm{d}^{-1}$. However, in tropical ectothermic taxa, such as $H$. squamata, acclimation capacities are limited as these organisms usually live close to their upper thermal tolerance limits (Pörtner and Knust 2007; Bruton et al. 2012; Shah et al. 2017).
As a more general consequence of this limitation, numerous tropical marine invertebrates will presumably not be able to react to ocean warming by adapting or acclimating or by shifting their distributional range at the same pace as warming occurs. Hence, population and community structures in tropical habitats will very likely change, since the abundances of less tolerant taxa will generally decline and local populations may even go extinct (Pörtner 2002; Pörtner and Knust 2007; Hiddink et al. 2015).

In addition to this direct impact of warming on vulnerable species (Pörtner 2001; Stillman 2003), populations can also be impaired indirectly when trophic interactions are altered (Beaugrand et al. 2003). The latter can lead to temperatureinduced shifts in the spatial or temporal distribution of predators or their prey (Müller-Navarra et al. 1997; Perry et al. 2005). Furthermore, a predator can change its performance, when, for instance, its feeding rates are increased (Harianto et al. 2018) or decreased (this study) as a consequence of ocean warming. Both effects can impact the ecological equilibrium in an ecosystem such as a coral reef. Abalone, however, are supposed to have only a minor direct impact on coral reefs, since they do not feed exclusively on attached macroalgae, but also consume drifting algal fragments (Shepherd 1973; Miner et al. 2006). Nevertheless, they are considered important as they are natural competitors of sea urchins, which co-occur in reef systems and also consume macroalgae (Lowry and Pearse 1973). Hence, the habitat and food preferences of abalone and sea urchins, which are an important group of benthic herbivores, overlap at least partly. A decrease in abalone abundances or a decline in their feeding rates could promote sea urchin populations by releasing them from competitive pressure. However, such a positive influence could be counteracted by the fact that sea urchins and other ectothermic herbivores, including herbivorous fish, might react to ocean warming in a similar way as the abalone in our study. Predicting how marine ecosystems such as coral reefs, which are partly shaped by the influence of herbivores, will change as a consequence of warming is, therefore, a challenge for ecologists.

Elevated temperatures also modified the palatability of the macroalgae that we offered to the abalone. Feeding rates of non-acclimated $H$. squamata decreased marginally (6\%) when they were offered macroalgae previously acclimated to $29^{\circ} \mathrm{C}$ and substantially (45\%) when the algae were kept at $31{ }^{\circ} \mathrm{C}$. At the same time, the relative preferences of the abalone for the offered macroalgae did not change. Since in this experimental scenario only the macroalgae but not the grazers were acclimated, the reduction in food consumption must have resulted exclusively from the influence of warming on the macroalgae.

Several effects of ocean warming on marine macrophytes have already been described. It is, for example, known that growth rates of marine primary producers can vary strongly 
with temperature (Raven and Geider 1988; Poore et al. 2016; Pagès et al. 2017). While this seems to be a common finding, Poore et al. (2013) did not find an effect of increased temperature on growth in the brown macroalga Sargassum linearifolium. Andersen et al. (2013) showed that a rise in water temperature by $5{ }^{\circ} \mathrm{C}$ above the ambient level weakened the thalli and led to tissue loss in the cold-temperate kelp species Saccharina latissima, while Raddatz et al. (2017) and Poore et al. (2013) found reduced palatability after exposure to increased temperatures in the brown algae Fucus vesiculosus and Sargassum linearifolium. In contrast to the latter observations, Gutow et al. (2016) did not observe any consequence of warming for herbivores feeding on the temperate/ cold-temperate species Fucus vesiculosus. Finally, Rothäusler et al. (2017) even showed an increase in palatability in F. vesiculosus that was previously acclimated to elevated temperatures. These diverse results indicate that reactions to warming can vary greatly among macroalgal species and maybe even among populations of the same species.

Changes in the nutritional value or in the defence status of the macroalgae in our study may have led to their reduced palatability after acclimation to elevated temperatures. Schram et al. (2017), for instance, showed reduced lipid concentrations in the macroalga Desmarestia anceps after it was exposed to elevated temperatures, and Raddatz et al. (2017) found that warming reduced the palatability of $F$. vesiculosus by changing its $\mathrm{C} / \mathrm{N}$ ratio. The latter can increase as a response to warming (Staehr and Wernberg 2009; Weinberger et al. 2011) and this reduces the nutritional value of algal tissue (van de Waal et al. 2010). This, in turn, may lead to an increase in feeding rates, since the herbivores need to compensate for the reduced energy uptake per unit biomass (Cruz-Rivera and Hay 2000). Since we observed the opposite picture, it is more likely that the lowered feeding rates in H. squamata in our study had another cause, e.g. secondary metabolites that were produced as a reaction to the heat stress, and which had a deterrent effect on the herbivores.

In the face of warming, $H$. squamata not only changed its feeding rates but also its feeding preference. At the lowest temperature, it preferred the red alga Gracilaria salicornia, but consumption of this species was lower after $\mathrm{H}$. squamata had been acclimated to $29^{\circ} \mathrm{C}$ and $31^{\circ} \mathrm{C}$. In contrast to this, consumption of the Amphiroa spp. was low at $27^{\circ} \mathrm{C}$, but increased after the herbivores were acclimated to $31^{\circ} \mathrm{C}$. At all temperatures, Sargassum spp. were by far the least attractive of the seaweeds. The preference for $G$. salicornia at the ambient water temperature of $27{ }^{\circ} \mathrm{C}$ is in line with other studies that found that Haliotis species from Southeast Asia and Australia predominantly feed on red macroalgae (Sheperd and Steinberg 1992; McShane et al. 1994; Tahil and Juinio-Menez 1999). A more recent study also found that for some Australian wild abalone populations brown algae are even more important than red algae (Guest et al.
2008). However, for $H$. squamata, two previous studies support our observation of a preference for Gracilaria sp. and the shunning of Sargassum spp. (Heru Prihadi et al. 2018; Yusup et al. 2020).

We report the first evidence of a temperature-induced change in the feeding preference of a marine herbivore from a multiple-choice experiment. Our finding is in line with that of Sotka and Giddens (2009) who observed that exposure to elevated temperatures changed food preference in the temperate herbivores Ampithoe longimana in a two-way choice assay. Interestingly, while this study focussed on temperate and subtropical amphipod populations, it only found an effect of warming on food choice in the northern herbivores. In contrast to this, the amphipod Gondogeneia antarctica, which occurs along the western Antarctic Peninsula, did not change its feeding preference as a reaction to elevated temperatures (Schram et al. 2017).

A possible explanation for the change in preference in our study is that metabolic rates in $H$. squamata increased under the elevated temperatures (Pörtner 2010). This may have impaired the abalone's capacity to discriminate between food types, due to its elevated energy demand (Cronin and Hay 1996). Furthermore, abalone are slow-moving animals and, hence, cannot easily escape from warm waters (Perry et al. 2005), while they, as an alternative strategy, could change their food source to cope with an increased or altered nutritional demand. It is assumed that organisms that need to increase their energy uptake, either seek food with a higher nutritional value or, if this is not possible, decrease the ingestion time to consume more biomass per unit time (e.g. reviewed by Pyke et al. 1977). In multiple-choice experiments with herbivores and carnivores, ectothermic species mostly choose the food with the highest nutritional value (Cruz-Rivera and Hay 2000) and show preference for food with a high content of carbohydrates (Lee et al. 2015).

Our results indicate that ocean warming can alter the performance of the marine herbivore $H$. squamata. Its feeding rates declined substantially under temperatures that were up to $4{ }^{\circ} \mathrm{C}$ above the current ambient temperature. We further found that $H$. squamata changed its food preference when it was acclimated to elevated temperatures, whereas there was no such switch when only the macroalgae were acclimated. We therefore conclude that the driver of the change in the feeding preference of $H$. squamata was in the herbivore itself. These findings demonstrate how ocean warming can affect the feeding behaviour of herbivores in coral reef communities and emphasise the need for more research on warming-induced shifts in the composition of herbivore diets.

Supplementary Information The online version contains supplementary material available at https://doi.org/10.1007/s00227-021-03922-y. 
Acknowledgements We wish to thank Sonja Kleinertz for supporting us on administrative and organisational aspects and we are thankful to Chuldyah Jengkarili Harsindhi, Fanny Kristiadhi, Muhammad Halim, and Firman Wira Pratama for helping us during sampling and with laboratory work. This study was conducted in the framework of the international research and student training programme GAME (Global Approach by Modular Experiments), which is coordinated by GEOMAR Helmholtz Centre for Ocean Research Kiel, Germany. We thank the sponsors of GAME for their support in 2018.

Authors' contributions Conceptualization: ML (50\%), VM (20\%), ANS (20\%), and NZ (10\%); methodology: VM (50\%) and ANS (50\%); formal analysis and investigation: VM (60\%), ML (30\%), and ANS (10\%); writing — original draft preparation: VM (100\%); writing - review and editing: ML (85\%), ANS (10\%), and NZ (5\%); resources: NZ (75\%) and ML (25\%); supervision: ML (90\%) and NZ (10\%).

Funding Open Access funding enabled and organized by Projekt DEAL. No funding was received for conducting this study.

Data availability All data used in this study will be made publicly available on PANGAEA (https://www.pangaea.de) following acceptance.

\section{Declarations}

Conflict of interest The authors declare that they have no conflict of interests.

Statement on animal welfare All the experiments were conducted in compliance with the guidelines of the IPB University and the Indonesian requirements of animal welfare.

Consent for publication All the authors have approved the version of the manuscript to be published.

Consent to participate Not applicable.

Open Access This article is licensed under a Creative Commons Attribution 4.0 International License, which permits use, sharing, adaptation, distribution and reproduction in any medium or format, as long as you give appropriate credit to the original author(s) and the source, provide a link to the Creative Commons licence, and indicate if changes were made. The images or other third party material in this article are included in the article's Creative Commons licence, unless indicated otherwise in a credit line to the material. If material is not included in the article's Creative Commons licence and your intended use is not permitted by statutory regulation or exceeds the permitted use, you will need to obtain permission directly from the copyright holder. To view a copy of this licence, visit http://creativecommons.org/licenses/by/4.0/.

\section{References}

Alcantara ALB, Noro T (2005) Effects of macroalgal type and water temperature on macroalgal consumption rates of the abalone Haliotis diversicolor Reeve. J Shellfish Res 24:1169-1177. https://doi. org/10.2983/0730-8000(2005)24[1169:eomtaw]2.0.co;2

Andersen G, Pedersen M, Nielsen S (2013) Temperature acclimation and heat tolerance of photosynthesis in Norwegian Sachharina latissima. J Phycol 700:689-700. https://doi.org/10.1111/j.15298817.2013.12077
Angell AR, Pirozzi I, de Nys R, Paul NA (2012) Feeding preferences and the nutritional value of tropical algae for the abalone Haliotis asinina. PLoS ONE 7:1-10. https://doi.org/10.1371/journal. pone. 0038857

Bachry S, Solihin DD, Gustiano R, Soewardi K, Butet NA (2019) Morphometric character and morphology of abalone Haliotis squamata Reeve 1864 in coastal southern Java and Bali. J Ilmu Dan Teknol Kelaut Trop 11:273-284

Beaugrand G, Brandner KM, Lindley JA, Souissi S, Reid PC (2003) Plankton effect on cod recruitment in the North Sea. Nature 254:2001-2004

Bruton MJ, Conservancy AW, Cramp RL, Franklin CE (2012) Benefits of thermal acclimation in a tropical aquatic ectotherm, the Arafura filesnake, Acrochordus arafurae. J Comp Physiol B. https://doi. org/10.1007/s00360-011-0643-6

Christensen AB, Nguyen HD, Byrne M (2011) Thermotolerance and the effects of hypercapnia on the metabolic rate of the ophiuroid Ophionereis schayeri: inferences for survivorship in a changing ocean. J Exp Mar Bio Ecol 403:31-38. https://doi.org/10.1016/j. jembe.2011.04.002

Clarke A, Fraser KPP (2004) Why does metabolism scale with temperature? Funct Ecol 18:243-251. https://doi.org/10.1111/j.02698463.2004.00841.x

Cronin G, Hay ME (1996) Susceptibility to herbivores depends on recent history of both the plant and animal. Ecology 77:1531-1543

Cruz-Rivera E, Hay ME (2000) Can quantity replace quality? Food choice, compensatory feeding, and fitness of marine mesograzers. Ecology 281:201-219. https://doi.org/10.1007/ s00227-006-0307-3

Delorme NJ, Sewell MA (2016) Effects of warm acclimation on physiology and gonad development in the sea urchin Evechinus chloroticus. Comp Biochem Physiol 198:33-40. https://doi.org/10. 1016/j.cbpa.2016.03.020

Geiger DL (2000) Distribution of and biogeography the recent Haliotidae (Gastropoda: Vetigastropoda) world-wide. Malacologico 35:57-120

Giri NA, Marzuqi M, Rusdi I, Andriyanto W (2016) Formulasi pakan buatan dengan bahan baku rumput laut untuk pertumbuhan abalon Haliotis squamata. J Ris Akuakultur 11:75. https://doi.org/10. 15578/jra.11.1.2016.75-83

Guest MA, Nichols PD, Frusher SD, Hirst AJ (2008) Evidence of abalone (Haliotis rubra) diet from combined fatty acid and stable isotope analyses. Mar Biol 153:579-588. https://doi.org/10.1007/ s00227-007-0831-9

Gutow L, Petersen I, Bartl K, Huenerlage K (2016) Marine meso-herbivore consumption scales faster with temperature than seaweed primary production. J Exp Mar Bio Ecol 477:80-85. https://doi. org/10.1016/j.jembe.2016.01.009

Harianto J, Dao H, Sebastian N, Maria PH (2018) The effect of warming on mortality, metabolic rate, heat—shock protein response and gonad growth in thermally acclimated sea urchins (Heliocidaris erythrogramma). Mar Biol 165:1-12. https://doi.org/10.1007/ s00227-018-3353-8

Heru Prihadi T, Rasidi AI, Widiyati A, Budi Wiyanto D (2018) Potency of different seaweeds as diets for developing abalone $(H$. squamata) culture in Nusa Penida Island, Bali. E3S Web Conf 47:1-8. https://doi.org/10.1051/e3sconf/20184702004

Hiddink JG, Burrows MT, García Molinos J (2015) Temperature tracking by North Sea benthic invertebrates in response to climate change. Glob Chang Biol 21:117-129. https://doi.org/10.1111/ gcb. 12726

Hill DK, Magnuson JJ (1990) Potential effects of global climate warming on the growth and prey consumption of Great Lakes fish. Trans Am Fish Soc. https://doi.org/10.1577/1548-8659(1990) 119\%3c0265:PEOGCW\%3e2.3.CO;2 
Hoegh-Guldberg O, Cai R, Poloczanska ES, Brewer PG, Sundby S, Hilmi K, Fabry VJ, Jung S (2014) The Ocean. In:Climate Change 2014: Impacts, adaptation, and vulnerability. Part B: Regional aspects. Contribution of working Group II to the Fifth Assessment Report of the Intergovernmental Panel on Climate Change

Hughes TP, Baird AH, Bellwood DR, Card M, Connolly SR, Folke C, Grosberg R, Hoegh-Guldberg O, Jackson JBC, Kleypas J, Lough JM, Marshall P, Nyström M, Palumbi SR, Pandolfi JM, Rosen B, Roughgarden J (2003) Climate change, human impacts, and the resilience of coral reefs. Science 301:929-933. https://doi.org/10. $1126 /$ science. 1085046

IPCC Working Group 1 (2013a) Long-term climate change: projections, commitments and irreversibility

IPCC Working Group 1 (2013b) Observations: ocean

Johnson MD, Carpenter RC (2012) Ocean acidification and warming decrease calcification in the crustose coralline alga Hydrolithon onkodes and increase susceptibility to grazing. J Exp Mar Bio Ecol 434-435:94-101. https://doi.org/10.1016/j.jembe.2012.08. 005

Lee KP, Jang T, Ravzanaadii N, Rho MS (2015) Macronutrient balance modulates the temperature-size rule in an ectotherm. Am Nat 186:212-222. https://doi.org/10.1086/682072

Leibold MA, Chase JM, Shurin JB, Downing AL (1997) Species turnover and the regulation of trophic structure. Annu Rev Ecol Syst 28:467-494. https://doi.org/10.1146/annurev.ecolsys.28.1.467

Lowry LF, Pearse JS (1973) Abalones and sea urchins in an area inhabited by sea otters. Mar Biol 9:213-219

Lubchenco J, Gaines SD (1981) A unified approach to marine plantherbivore interactions. II. Populations and communities. Annu Rev Ecol Syst 12:405-437

McShane PE, Gorfine HK, Knuckey IA (1994) Factors influencing food selection in the abalone Haliotis rubra (Mollusca: Gastropoda). J Exp Mar Bio Ecol 176:27-37. https://doi.org/10.1016/00220981(94)90195-3

Miller AD, Hoffmann AA, Tan MH, Young M, Ahrens C, Cocomazzo M, Rattray A, Ierodiaconou DA, Treml E, Sherman CDH (2019) Local and regional scale habitat heterogeneity contribute to genetic adaptation in a commercially important marine mollusc (Haliotis rubra) from southeastern Australia. Mol Ecol 28:30533072. https://doi.org/10.1111/mec.15128

Miner CM, Alstatt JM, Raimondi PT, Minchinton TE (2006) Recruitment failure and shifts in community structure following mass mortality limit recovery prospects of black abalone. Mar Ecol Prog Ser 327:107-117

Müller-Navarra DC, Güss S, Von Storch H (1997) Interannual variability of seasonal succession events in a temperate lake and its relation to temperature variability. Glob Chang Biol 3:429-438. https://doi.org/10.1046/j.1365-2486.1997.00080.x

Nguyen KDT, Morley SA, Lai CH, Clark MS, Tan KS, Bates AE, Peck LS (2011) Upper temperature limits of tropical marine ectotherms: Global warming implications. PLoS ONE 6:6-13. https:// doi.org/10.1371/journal.pone.0029340

O'Connor MI, Piehler MF, Leech DM, Anton A, Bruno JF (2009) Warming and resource availability shift food web structure and metabolism. PLoS Biol 7:3-8. https://doi.org/10.1371/journal. pbio. 1000178

Oksanen J, Blanchet GF, Friendly M, Kindt R, Legendre P, McGlinn D, Minchin PR, O'Hara RB, Simpson GL, Solymos P, Stevens MHH, Szoecs E, Wagner H (2019) vegan: Community ecology package

Pagès JF, Romero J, Smith TM, Pérez M, Sanmartí N, De Bari H, Boada J, Tomas F, Alcoverro T, Arthur R (2017) Contrasting effects of ocean warming on different components of plant-herbivore interactions. Mar Pollut Bull 134:55-65. https://doi.org/10. 1016/j.marpolbul.2017.10.036

Perry AL, Low PJ, Ellis JR, Reynolds JD (2005) Climate change and distribution shifts in marine fishes. Science 308:1912-1916
Poore AGB, Graba-Landry A, Favret M, Sheppard Brennand H, Byrne M, Dworjanyn SA (2013) Direct and indirect effects of ocean acidification and warming on a marine plant-herbivore interaction. Oecologia 173:1113-1124. https://doi.org/10.1007/ s00442-013-2683-y

Poore AGB, Graham SE, Byrne M, Dworjanyn SA (2016) Effects of ocean warming and lowered $\mathrm{pH}$ on algal growth and palatability to a grazing gastropod. Mar Biol 163:1-11. https://doi.org/10.1007/ s00227-016-2878-y

Pörtner HO (2001) Climate change and temperature-dependent biogeography: oxygen limitation of thermal tolerance in animals. Naturwissenschaften 88:137-146. https://doi.org/10.1007/s0011 40100216

Pörtner HO (2002) Environmental and functional limits to muscular exercise and body size in marine invertebrate athletes. Comp Biochem Physiol 133:303-321

Pörtner HO (2010) Oxygen- and capacity-limitation of thermal tolerance : a matrix for integrating climate-related stressor effects in marine ecosystems. J Exp Biol. https://doi.org/10.1242/jeb. 037523

Pörtner HO, Knust R (2007) Climate change affects marine fishes through the oxygen limitation of thermal tolerance. Science 315:95-98. https://doi.org/10.1126/science.1135471

Pörtner HO, Farrell AP, Knust R, Lannig G, Mark FC, Storch D (2009) Adapting to climate change-response. Science 323:876-877

Pyke GH, Pulliam HR, Charnov EL (1977) Optimal foraging: a selective review of theory and tests. Q Rev Biol 52:137-154

Raddatz S, Guy-Haim T, Rilov G, Wahl M (2017) Future warming and acidification effects on anti-fouling and anti-herbivory traits of the brown alga Fucus vesiculosus (Phaeophyceae). J Phycol 53:44-58. https://doi.org/10.1111/jpy.12473

Raven JA, Geider RJ (1988) Temperature and algal growth. New Phytol 110:441-461

Rothäusler E, Haavisto F, Jormalainen V (2017) Is the future as tasty as the present? Elevated temperature and hyposalinity affect the quality of Fucus (Phaeophyceae, Fucales) as food for the isopod Idotea balthica. Mar Biol 164:1-15. https://doi.org/10.1007/ s00227-017-3237-3

Schram JB, Schoenrock KM, McClintock JB, Amsler CD, Angus RA (2017) Ocean warming and acidification alter Antarctic macroalgal biochemical composition but not amphipod grazer feeding preferences. Mar Ecol Prog Ser 581:45-56. https://doi.org/10. 3354/meps 12308

Schulte PM, Healy TM, Fangue NA (2011) Thermal performance curves, phenotypic plasticity, and the time scales of temperature exposure. Integr Comp Biol 51:691-702. https://doi.org/10.1093/ icb/icr097

Shah AA, Funk WC, Ghalambor CK (2017) Integrative and comparative biology thermal acclimation ability varies in temperate and tropical aquatic insects from different elevations. Integr Comp Biol 57:977-987. https://doi.org/10.1093/icb/icx101

Sheperd SA, Steinberg PD (1992) Food preferences of three Australian abalone species with a review of the algal food of abalone. In: Abalone of the world:biology, fisheries, and culture. Fishing News Books Ltd pp 169-181

Shepherd SA (1973) Studies on southern Australian abalone (genus Haliotis). Aust J Mar Freswat Res 24:217-257

Shiel BP, Cooke IR, Hall NE, Robbinson NA, Strugnell JM (2020) Gene expression differences between abalone that are susceptible and resilient to a simulated heat wave event. Aquaculture. https:// doi.org/10.1016/j.aquaculture.2020.735317

Sokolova IM, Pörtner HO (2001) Physiological adaptations to high intertidal life involve improved water conservation abilities and metabolic rate depression in Littorina saxatilis. Mar Ecol Prog Ser 224:171-186. https://doi.org/10.3354/meps224171 
Somero GN (2002) Thermal physiology and vertical zonation of intertidal animals: optima, limits, and costs of living. Integr Comp Biol 42:780-789. https://doi.org/10.1093/Icb/42.4.780

Somero GN, Hochachka PW (1971) Biochemical adaptation to the environment. Am Zool 11:159-167. https://doi.org/10.1093/icb/ 11.1.159

Sotka EE, Giddens H (2009) Seawater temperature alters feeding discrimination by cold-temperate but not subtropical individuals of an ectothermic herbivore. Biol Bull 216:75-84. https://doi.org/ 10.1086/BBLv216n1p75

Staehr PA, Wernberg T (2009) Physiological responses of Ecklonia radiata (Laminariales) to a lattitudinal gradient in ocean temperature. J Phycol 99:91-99. https://doi.org/10.1111/j.1529-8817. 2008.00635.x

Stillman JH (2003) Acclimation capacity underlies susceptibility to climate change. Science 301:65. https://doi.org/10.1126/science. 1083073

Suci ANN, Bengen DG, Zamani NP (2019) Maximum thermal tolerance of tropical marine gastropods, Haliotis squamata (Reeve 1846). J Ilmu Dan Teknol Kelaut Trop 11:595-600. https://doi. org/10.13841/j.cnki.jxsj.2013.01.021

Susanto B, Rusdi I, Ismi S, Rahmawati dan R (2010) Pemeliharaan yuwana abalon Haliotis squamata turunan F-1 secara terkontrol dengan jenis pakan berbeda. J Ris Akuakultur 5:199-209

Tahil AS, Juinio-Menez MA (1999) Natural diet, feeding periodicity and functional response to food density of the abalone, Haliotis asinina L., (Gastropoda). Aquac Res 30:95-107. https://doi.org/ 10.1046/j.1365-2109.1999.00294.x

Tutschulte T, Connell J (1988) Feeding behavior and algal food of three species of abalones (Haliotis) in southern California. Mar Ecol Prog Ser 49:57-64. https://doi.org/10.3354/meps049057

van de Waal DB, Verschoor AM, Verspagen JMH, van Donk E, Huisman J (2010) Climate-driven changes in the ecological stoichiometry of aquatic ecosystems. Front Ecol Environ 8:145152. https://doi.org/10.1890/080178

Vasseur DA, Delong JP, Gilbert B, Greig HS, Harley CDG, Mccann KS, Savage V, Tunney TD, Connor MIO (2014) Increased temperature variation poses a greater risk to species than climate warming. Proc R Soc B. https://doi.org/10.1098/rspb.2013.2612

Weinberger F, Rohde S, Oschmann Y, Shahnaz L, Dobretsov S, Wahl M (2011) Effects of limitation stress and of disruptive stress on induced antigrazing defense in the bladder wrack Fucus vesiculosus. Mar Ecol Prog Ser 427:83-94. https://doi.org/10.3354/meps0 9044

Yusup DS, Mahardika IG, Suarna IW, Giri INA (2020) Feeding preference and growth response of early adults abalone, Haliotis squamata on some macroalgae. Biodiversitas 21:4369-4375. https:// doi.org/10.13057/biodiv/d210956

Zeeman Z, Branch GM, Peschak TP, Pillay D (2012) Assessing the ecosystem effects of the abalone Haliotis midae from its diet and foraging behaviour. Afr J Mar Sci 34:205-214. https://doi.org/10. 2989/1814232X.2012.675119

Zeeman Z, Branch GM, Pillay D, Jarre A (2014) An experimental test of the effect of the abalone Haliotis midae on benthic community composition. Mar Biol 161:329-337. https://doi.org/10. 1007/s00227-013-2338-x

Zhang P, Blonk BA, Van Den BRF, Bakker ES (2016) The effect of temperature on herbivory by the omnivorous ectotherm snail Lymnaea stagnalis. Hydrobiologia 812:147-155. https://doi.org/10. 1007/s10750-016-2891-7

Publisher's Note Springer Nature remains neutral with regard to jurisdictional claims in published maps and institutional affiliations. 